\title{
A meta-analysis of feed digestion in dairy cows. 2. The effects of feeding level and diet composition on digestibility
}

\author{
P. Huhtanen, ${ }^{* 1,2} M$. Rinne, $†$ and J. Nousiainen $\ddagger$ \\ ${ }^{*}$ Cornell University, Department of Animal Science, 269 Morrison Hall, Ithaca, NY 14853-4801 \\ †MTT Agrifood Research Finland, Animal Production Research, FI-31600, Jokioinen, Finland \\ ¥Valio Ltd., Farm Services, PO Box 10, FI-00039 Valio, Finland
}

\section{ABSTRACT}

A meta-analysis based on published experiments with lactating dairy cows fed mainly grass silage-based diets was conducted to study the effects of intake, diet composition, and digestibility at a maintenance level of feeding on the apparent total diet digestibility. A data set that included a total of 497 dietary treatment means from 92 studies was collected and analyzed using mixed model regression analysis with a random study effect. Diet organic matter digestibility (OMD) in dairy cows at a production level $\left(\mathrm{OMD}_{\mathrm{p}}\right)$ was positively associated with $\mathrm{OMD}$ at maintenance $\left(\mathrm{OMD}_{\mathrm{m}}\right)$, but the slope was less than 1 (0.69). Diet $\mathrm{OMD}_{\mathrm{p}}$ decreased as feed intake increased, and diets with high $\mathrm{OMD}_{\mathrm{m}}$ exhibited greater depressions in digestibility with increased intake than did diets with low $\mathrm{OMD}_{\mathrm{m}}$. Digestibility of organic matter and neutral detergent fiber (NDF) increased as dietary crude protein concentration increased, whereas increased concentrate fat decreased digestibility. Replacement of grass silage with whole-crop cereal silage was associated with a quadratic decrease in diet digestibility. Metabolic fecal output, defined as fecal organic matter minus NDF, averaged $95.8(\mathrm{SE}=0.65) \mathrm{g} / \mathrm{kg}$ of dry matter intake, and it was not influenced by intake or diet composition. Variation in $\mathrm{OMD}_{\mathrm{p}}$ in cows fed grass silage-based diets was therefore attributable to variation in dietary NDF concentration and NDF digestibility. Depression in digestibility of organic matter with increased intake was less than predicted by the National Research Council and Cornell Net Carbohydrate and Protein systems. The following 2-parameter model indicates that the difference between OMD estimated in sheep fed at maintenance compared with dairy cows at production level is related both to dry matter intake and digestibility at maintenance level: $\mathrm{OMD}_{\mathrm{p}}=257$

\footnotetext{
Received October 24, 2008.

Accepted June 25, 2009.

${ }^{1}$ Corresponding author: pekka.huhtanen@njv.slu.se

${ }^{2}$ Current address: Department of Agricultural Research for Northern Sweden, Swedish University of Agricultural Sciences (SLU), Umeå, Sweden.
}

$( \pm 43)+0.685( \pm 0.054) \times \mathrm{OMD}_{\mathrm{m}}(\mathrm{g} / \mathrm{kg}$ of dry matter $)$ $-2.6( \pm 0.44) \times$ dry matter intake $(\mathrm{kg} / \mathrm{d})$; adjusted residual mean square error $=8.4 \mathrm{~g} / \mathrm{kg}$. It was concluded that diet digestibility in dairy cows can be predicted accurately and precisely from digestibility estimated at maintenance intake in sheep by using regression models including animal and dietary factors.

Key words: digestibility, feed intake, dairy cow, grass silage

\section{INTRODUCTION}

Traditionally, the tabulated feed values for cattle are computed using the digestibility coefficients estimated with sheep fed at a maintenance feeding level, and the energy value of the diet is assumed to be the sum of individual diet components. Laboratory methods used to estimate forage digestibility or energy concentration are usually calibrated against digestibility measured with sheep at a maintenance level of feeding (Huhtanen et al., 2006). Generally, the digestibility coefficients are similar in sheep and cattle (Yan et al., 2002), but it is well known that diet digestibility decreases with increased feeding level; therefore, the energy values are adjusted for the level of feeding in some feed evaluation systems (Agricultural and Food Research Council, 1993; NRC, 2001).

Further, feeding level effects on diet digestibility are not constant but depend on diet composition (Tyrrel and Moe, 1975; Colucci et al., 1982, 1990; NRC, 2001; Yan et al., 2002). Consequently, associative effects between dietary components combined with feeding level responses lead to significant overprediction of energy intake when the digestibility values determined at a maintenance level of feeding are applied to dairy cows fed mixed diets at high levels of intake.

In an accompanying paper (Nousiainen et al., 2009), we analyzed the effects of specific forage and concentrate factors on diet $\mathrm{OM}$ and NDF digestibility. This analysis demonstrated that, in addition to the effects of feeding level, many other factors had a significant effect on digestibility in studies in which only one specific factor varied. For example, increasing dietary $\mathrm{CP}$ 
concentration by replacing energy supplements with protein supplements improved OM and NDF digestibility in dairy cows. On the other hand, digestibility was not improved in dairy cows with increased concentrate supplementation despite an increase in predicted digestibility at a maintenance level of feeding (Nousiainen et al., 2009). This suggests that other factors in addition to feeding level should be included in empirical equations in feed evaluation systems to predict digestibility and energy concentration in dairy cow diets from digestibility estimates at maintenance. The objectives of the present study were to develop prediction equations estimating OM and NDF digestibility, and depressions in digestibility in response to changes in feeding level and specific dietary factors reported in the accompanying study (Nousiainen et al., 2009) from a data set of dairy cow experiments in which grass silage was the main forage source.

\section{MATERIALS AND METHODS}

\section{Data}

Treatment mean data were collected from feeding trials with lactating dairy cows fed grass silage ad libitum or grass silage partly or completely substituted for legume (mainly red clover) silage or whole-crop cereal (mainly barley and wheat) silage. A detailed description of the data was presented by Nousiainen et al. (2009) and in the publications associated with individual studies (Appendix in the article by Nousiainen et al., 2009, includes a list of references). The total data included 497 diets in 92 studies.

\section{Calculations}

Calculations of diet OM digestibility (OMD) at a maintenance level of feeding $\left(\mathbf{O M D}_{\mathrm{m}}\right)$ and estimation of dietary concentrations of indigestible NDF were reported in the previous paper (Nousiainen et al., 2009). Forage $\mathrm{OMD}_{\mathrm{m}}$ was determined either in vivo in sheep fed forage alone at a maintenance level $(\mathrm{n}=222)$ or by using in vitro methods $(\mathrm{n}=275)$. Dietary concentration of potentially digestible NDF (pdNDF; $\mathrm{g} / \mathrm{kg}$ of $\mathrm{DM}$ ) was calculated as NDF minus indigestible NDF ( $\mathrm{g} / \mathrm{kg}$ of DM). Diet digestibility in dairy cows at a production level was determined either by the total fecal collection method $(\mathrm{n}=176)$ or by using acid-insoluble ash, determined as described by Van Keulen and Young (1977) as an internal marker $(\mathrm{n}=321)$.

True digestibility and metabolic fecal output of neutral detergent solubles (NDS) and CP were estimated by the Lucas test. The purpose of the Lucas test is to discover feed entities behaving uniformly over a wide range of feedstuffs by plotting the digestible amount against the total intake of the component. The slope of the regression equation predicts the true digestibility of the component, and the intercept is an estimate of the fecal metabolic fraction (see Van Soest, 1994).

Concentration of the total digestible nutrients (TDN) at a maintenance level of feeding $\left(\mathbf{T D N}_{\mathrm{m}} ; \mathrm{g} / \mathrm{kg}\right.$ of DM) was calculated from digestible $\mathrm{OM}$ at maintenance $\left(\mathrm{DOM}_{\mathrm{m}}\right)$ as follows:

$$
\begin{gathered}
\mathrm{TDN}_{\mathrm{m}}=\mathrm{DOM}_{\mathrm{m}}+1.25 \\
\times \text { fatty acids }(\mathrm{g} / \mathrm{kg} \text { of DM }),
\end{gathered}
$$

to correct for the higher energy concentration of fat compared with the other digestible nutrients. Total digestible nutrients at a production level $\left(\mathbf{T D N} \mathbf{p}_{\mathrm{p}}\right)$ was calculated as $\mathrm{DOM}_{\mathrm{p}}+1.25 \times$ fatty acids, where $\mathrm{DOM}_{\mathrm{p}}$ is the concentration of DOM determined in digestibility trials with cows. Because the ether extract contains, in addition to fatty acids, many other compounds of lower energy content, such as waxes, empirical relationships between ether extract and fatty acid concentrations were used:

$$
\begin{gathered}
\text { Forage fatty acids }(\mathrm{g} / \mathrm{kg} \text { of } \mathrm{DM})=0.48 \\
\times \text { ether extract }-1.3, \\
\text { Concentrate fatty acids }(\mathrm{g} / \mathrm{kg} \text { of } \mathrm{DM})=0.904 \\
\times \text { ether extract }-3.6 .
\end{gathered}
$$

For fatty acids, a value of zero was used when the ether extract concentrations in forage and concentrates were below 2.7 and $4.0 \mathrm{~g} / \mathrm{kg}$ of DM, respectively. The equations are based on an unpublished Nordic data set.

The $\mathrm{TDN}_{\mathrm{p}}$ was calculated according to NRC (2001) by using the following equation to discount for the reduced digestibility with increased feeding level:

$$
\begin{gathered}
\mathrm{TDN}_{\mathrm{p}}(\mathrm{g} / \mathrm{kg} \text { of DM })=\mathrm{TDN}_{\mathrm{m}} \\
-\left[\left(0.18 \times \mathrm{TDN}_{\mathrm{m}}-103\right) \times \mathrm{FL}\right],
\end{gathered}
$$

where FL is the feeding level multiple of maintenance minus 1. Feeding level was calculated according to NRC (2001). The Cornell Net Carbohydrate and Protein System (CNCPS) predicts the $\mathrm{TDN}_{\mathrm{p}}$ separately for the forage and concentrate components of the ration with the following equations (Fox et al., 2003): 


$$
\begin{aligned}
& \text { Forage } \mathrm{TDN}_{\mathrm{p}}=5.3+0.99 \times \mathrm{TDN}_{\mathrm{m}}-0.009 \\
& \times \mathrm{NDF}+0.000005 \times \mathrm{TDN}_{\mathrm{m}} \times \mathrm{NDF}+89.6 \\
& \times \mathrm{FL}-0.1 \times \mathrm{TDN}_{\mathrm{m}} \times \mathrm{FL}+0.00005 \\
& \times \mathrm{TDN}_{\mathrm{m}} \times \mathrm{NDF} \times \mathrm{FL},
\end{aligned}
$$

where the units of $\mathrm{NDF}$ and $\mathrm{TDN}_{\mathrm{m}}$ are grams per kilogram of DM; and

$$
\begin{gathered}
\text { Concentrate } \mathrm{TDN}_{\mathrm{p}}=1.01 \times \mathrm{TDN}_{\mathrm{m}} \\
-17.7 \times \mathrm{FL}-9.9 .
\end{gathered}
$$

\section{Statistical Analysis}

The data were analyzed using the mixed model procedure of SAS (Littell et al., 1996). The model was $\mathrm{Y}$ $=\mathrm{B}_{0}+\mathrm{B}_{1} \mathrm{X}_{1 \mathrm{ij}}+\mathrm{b}_{0}+\mathrm{b}_{1} \mathrm{X}_{1 \mathrm{ij}}+\mathrm{B}_{2} \mathrm{X}_{2 \mathrm{ij}}+\ldots+\mathrm{B}_{\mathrm{n}} \mathrm{X}_{\mathrm{nij}}+$ $\mathrm{e}_{\mathrm{ij}}$, where $\mathrm{B}_{0}, \mathrm{~B}_{1} \mathrm{X}_{1 \mathrm{ij}}$, and $\mathrm{B}_{2} \mathrm{X}_{2 \mathrm{ij}}, \ldots, \mathrm{B}_{\mathrm{n}} \mathrm{X}_{\mathrm{nij}}$ are the fixed effects and $b_{0}, b_{1}$, and $e_{i j}$ are the random experiment effects (intercept and slope), where $\mathrm{i}=1 \ldots \mathrm{n}$ studies and $\mathrm{j}=1 \ldots \mathrm{n}_{\mathrm{i}}$ values.

Two variable equations were developed to predict the effects of intrinsic $\left(\mathrm{OMD}_{\mathrm{m}}\right.$ or pdNDF/NDF) and extrinsic (DMI) factors on OMD at a production level $\left(\mathrm{OMD}_{\mathrm{p}}\right)$ or NDF digestibility (NDFD) at a production feeding level. Multiple regression models were developed by running multiple iterations in the mixed model procedure, beginning from the 2-variable models $\left(\mathrm{OMD}_{\mathrm{m}}\right.$ or pdNDF/NDF, and DMI), by including additional biologically relevant variables. The first 2 variables were selected because many current feed evaluation models correct $\mathrm{OMD}_{\mathrm{m}}\left(\right.$ or $\mathrm{TDN}_{\mathrm{m}}$ ) for feeding level effects. The NRC (2001) model also takes $\mathrm{TDN}_{\mathrm{m}}$ into account in calculating digestibility discounts. The selection of the other relevant parameters was based on our previous study (Nousiainen et al., 2009). Furthermore, the effects of some additional parameters (e.g., concentrations of dietary carbohydrates) were estimated. Finally, the quadratic terms and 2-way interactions were evaluated. In multiple regression models, $\mathrm{OMD}_{\mathrm{m}}$ or $\mathrm{pdNDF} / \mathrm{NDF}$ and DMI were considered to have a random slope. The variable whose inclusion reduced the residual variance the most was included in the model. This procedure was repeated until the residual variance did not decrease or the $P$-value of the last parameter was $>0.05$. The bestfit model was chosen based on the lowest residual mean square error (RMSE) and Akaike's information criterion. The RMSE values were adjusted for the random effect of experiment. The RMSE values between model predicted and observed in vivo TDN were calculated as RMSE $=\sqrt{ } \Sigma(\text { observed }- \text { predicted })^{2} /$ n. Mean squared prediction error (i.e., deviations from unity $=$ MSPE) was divided into components resulting from mean bias, slope bias, and random variation around the regression line (Bibby and Toutenburg, 1977). Discount equations were evaluated by regressing residual (observed minus predicted) values on the predicted values (St-Pierre, 2003). Predicted values were centered by subtracting the mean of all predicted values from each prediction. This makes the slope and intercept estimates in the regression orthogonal and thus independent. Mean biases were assessed by using the intercepts of the regression equations, and the slopes of the regression equations were used to determine the presence of linear biases.

When $\mathrm{OMD}_{\mathrm{m}}$ was derived from the in vitro data, $\mathrm{OMD}_{\mathrm{p}}$ is a prediction from a prediction, and there is an associated compounded variance that amplifies the error. A simulation study was conducted to evaluate the influence of covariance on the prediction error of $\mathrm{OMD}_{\mathrm{p}}$. The simulation data was based on the in vitro digestibility data (Huhtanen et al., 2006), in which the following relationship between $\mathrm{OMD}_{\mathrm{m}}$ and in vitro OM pepsin-cellulase solubility (OMS) was estimated: $\mathrm{OMD}_{\mathrm{m}}=38 \pm 20+0.89 \pm 0.026 \times$ OMS $(\mathrm{n}=86$; RMSE adjusted for a random study effect $=10.0 \mathrm{~g} /$ $\mathrm{kg})$. A value of $7.0 \mathrm{~g} / \mathrm{kg}$ was used as the error estimate of in vivo $\mathrm{OMD}_{\mathrm{m}}$ in sheep fed at maintenance (Nousiainen, 2004) and $\mathrm{OMD}_{\mathrm{p}}$ (present study). These values are based on residual standard deviations of $14 \mathrm{~g} / \mathrm{kg}$ in digestibility estimates and 4 animals per diet. The error for OMS $(9 \mathrm{~g} / \mathrm{kg})$ was obtained by iterating the random error of OMS to result in an error of $10 \mathrm{~g} / \mathrm{kg}$ in the predicted $\mathrm{OMD}_{\mathrm{m}}$, with an in vivo $\mathrm{OMD}_{\mathrm{m}}$ error of $7 \mathrm{~g} / \mathrm{kg}$.

A set of 20 correction equations was developed to predict $\mathrm{OMD}_{\mathrm{m}}$ from OMS by adding random errors (SD $=9$ and $7 \mathrm{~g} / \mathrm{kg}$ for OMS and $\mathrm{OMD}_{\mathrm{m}}$, respectively). Random errors were generated by the Microsoft Excel Random Number Generator (Microsoft Corporation, Redmond, WA). These correction equations were then used to predict $\mathrm{OMD}_{\mathrm{p}}$ from 20 independent data sets. These were developed from OMS, $\mathrm{OMD}_{\mathrm{m}}$, and $\mathrm{OMD}_{\mathrm{p}}$ by adding generated random errors. Digestibility at a production level was estimated using the relationship between $\mathrm{OMD}_{\mathrm{m}}$ and $\mathrm{OMD}_{\mathrm{p}}$ derived in the present study. A value of $7 \mathrm{~g} / \mathrm{kg}$ was used as the random error for $\mathrm{OMD}_{\mathrm{p}}$ (Nousiainen et al., 2009). In total, 20 correction equations and 20 independent data sets produced 400 comparisons of prediction errors of $\mathrm{OMD}_{\mathrm{p}}$, estimated directly from OMS or indirectly from $\mathrm{OMD}_{\mathrm{m}}$ predicted from OMS. The difference in the error of direct and indirect estimates of $\mathrm{OMD}_{\mathrm{p}}$ can be considered as compounded variance or regression error. 
Table 1. Statistical description of the variables used in the data file for prediction of digestibility in dairy cows fed grass silage-based diets

\begin{tabular}{|c|c|c|c|c|c|}
\hline Item & $\mathrm{n}$ & Mean & SD & Minimum & Maximum \\
\hline \multicolumn{6}{|l|}{ Intake (kg of DM/d) } \\
\hline Forage & 497 & 10.9 & 1.93 & 4.6 & 17.4 \\
\hline Concentrate & 497 & 7.7 & 2.47 & 0.0 & 18.4 \\
\hline Total & 497 & 18.6 & 2.98 & 9.9 & 25.2 \\
\hline Concentrate fat & 497 & 0.33 & 0.189 & 0.01 & 1.32 \\
\hline \multicolumn{6}{|l|}{ Production $(\mathrm{kg} / \mathrm{d})$} \\
\hline Milk & 497 & 26.7 & 5.06 & 13.0 & 45.8 \\
\hline ECM & 497 & 27.4 & 5.33 & 12.8 & 42.1 \\
\hline \multicolumn{6}{|l|}{ Digestibility (g/kg) } \\
\hline $\mathrm{OM}$ & 497 & 736 & 38.1 & 621 & 830 \\
\hline $\mathrm{CP}$ & 471 & 691 & 41.1 & 542 & 782 \\
\hline $\mathrm{NDF}$ & 388 & 627 & 71.8 & 408 & 830 \\
\hline $\mathrm{pdNDF}^{1}$ & 388 & 754 & 63.3 & 506 & 946 \\
\hline $\mathrm{MFOM}^{2}(\mathrm{~g} / \mathrm{kg}$ of DMI $)$ & 388 & 96 & 14.6 & 61 & 147 \\
\hline \multicolumn{6}{|l|}{ Diet composition ( $\mathrm{g} / \mathrm{kg}$ of $\mathrm{DM})$} \\
\hline $\mathrm{CP}$ & 497 & 166 & 20.0 & 111 & 229 \\
\hline NFC & 497 & 293 & 50.0 & 80 & 419 \\
\hline $\mathrm{NDF}$ & 497 & 419 & 47.0 & 283 & 559 \\
\hline Indigestible NDF & 497 & 68 & 22.4 & 19 & 148 \\
\hline Crude fat & 497 & 44 & 10.1 & 22 & 112 \\
\hline Starch & 497 & 141 & 56.3 & 0 & 292 \\
\hline Concentrate $\mathrm{WSC}^{3}$ & 497 & 60 & 38.5 & 8 & 306 \\
\hline Whole-crop silage ${ }^{4}(\mathrm{~kg} / \mathrm{kg})$ & 497 & 0.036 & 0.148 & 0.00 & 1.00 \\
\hline $\mathrm{OMD}_{\mathrm{m}}^{5}(\mathrm{~g} / \mathrm{kg})$ & 497 & 774 & 31.5 & 658 & 846 \\
\hline
\end{tabular}

${ }^{1}$ pdNDF $=$ potentially digestible NDF.

${ }^{2} \mathrm{MFOM}=$ metabolic fecal OM (calculated as OM $-\mathrm{NDF}$ ).

${ }^{3} \mathrm{WSC}=$ water-soluble carbohydrates $(\mathrm{g} / \mathrm{kg}$ of concentrate DM).

${ }^{4}$ Whole-crop cereal silage (proportion of forage DM).

${ }^{5} \mathrm{OMD}_{\mathrm{m}}=\mathrm{OM}$ digestibility determined at a maintenance level of feeding or with a corresponding in vitro method.

\section{RESULTS}

The data on feed intake, diet digestibility, and chemical composition of the diets are presented in Table 1 and discussed by Nousiainen et al. (2009).

\section{OMD}

The linear relationship between $\mathrm{OMD}_{\mathrm{m}}$ and $\mathrm{OMD}_{\mathrm{p}}$ determined in dairy cows is shown in Figure 1. The MSPE was $36.8 \mathrm{~g} / \mathrm{kg}$, with mean bias, slope, and random errors contributing proportionally $85.5,9.4$, and $5.1 \%$ of the mean square error. The parameter values of the 1-variable model with $\mathrm{OMD}_{\mathrm{m}}$ were not significantly different when the forage digestibility was determined in vivo or in vitro. The regression coefficients between $\mathrm{OMD}_{\mathrm{m}}$ and $\mathrm{OMD}_{\mathrm{p}}$ were 0.64 versus 0.61 for in vitro and in vivo data, respectively (pooled SE $0.049, t=0.64, P$ $=0.52$ ). The corresponding values for intercepts were 235 versus 281 (SE $37, t=1.24, P=0.21$ ). The RMSE adjusted for the study effect was smaller for the in vitro compared with the in vivo data (6.8 vs. $10.0 \mathrm{~g} / \mathrm{kg})$.

An equation for predicting $\mathrm{OMD}_{\mathrm{p}}$ in dairy cows that included $\mathrm{OMD}_{\mathrm{m}}$ and $\mathrm{DMI}$ as independent variables was developed using the whole data set $(\mathrm{n}=497)$ :

$$
\begin{gathered}
\mathrm{OMD}_{\mathrm{p}}=257( \pm 43)+0.685( \pm 0.054) \\
\times \mathrm{OMD}_{\mathrm{m}}(\mathrm{g} / \mathrm{kg} \text { of } \mathrm{DM})-2.6( \pm 0.44) \\
\times \mathrm{DMI}(\mathrm{kg} / \mathrm{d}) ; \text { adjusted RMSE }=8.4 \mathrm{~g} / \mathrm{kg} .
\end{gathered}
$$

The corresponding RMSE without adjusting for a random study effect was $22.8 \mathrm{~g} / \mathrm{kg}$. Equation [7] suggests that, proportionally, 0.69 of the increase in $\mathrm{OMD}_{\mathrm{m}}$ was detected in dairy cows and that $\mathrm{OMD}_{\mathrm{p}}$ decreased by $2.6 \mathrm{~g} / \mathrm{kg}$ per kilogram of increase in DMI. The quadratic effect of DMI tended $(P=0.07)$ to be significant, suggesting that depression in $\mathrm{OMD}_{\mathrm{p}}$ per kilogram of DMI tended to increase as intake increased. When the data were analyzed separately for the in vivo $(\mathrm{n}=222)$ and in vitro $(\mathrm{n}=275) \mathrm{OMD}_{\mathrm{m}}$ determinations with the 2-parameter model using $\mathrm{OMD}_{\mathrm{m}}$ and DMI as independent variables, the coefficients for $\mathrm{OMD}_{\mathrm{m}}$ were similar $(0.69 \pm 0.046$ vs. $0.68 \pm 0.043)$. Adjusted RMSE values were 10.6 and $8.5 \mathrm{~g} / \mathrm{kg}$ for the in vivo and in vitro data, and the corresponding unadjusted values were 20.9 and $21.3 \mathrm{~g} / \mathrm{kg}$, respectively. Adjusted values were greater than for the 1-parameter $\left(\mathrm{OMD}_{\mathrm{m}}\right)$ model, because the model did not converge when random slope was included for the in vitro data and only intercept was kept random. 


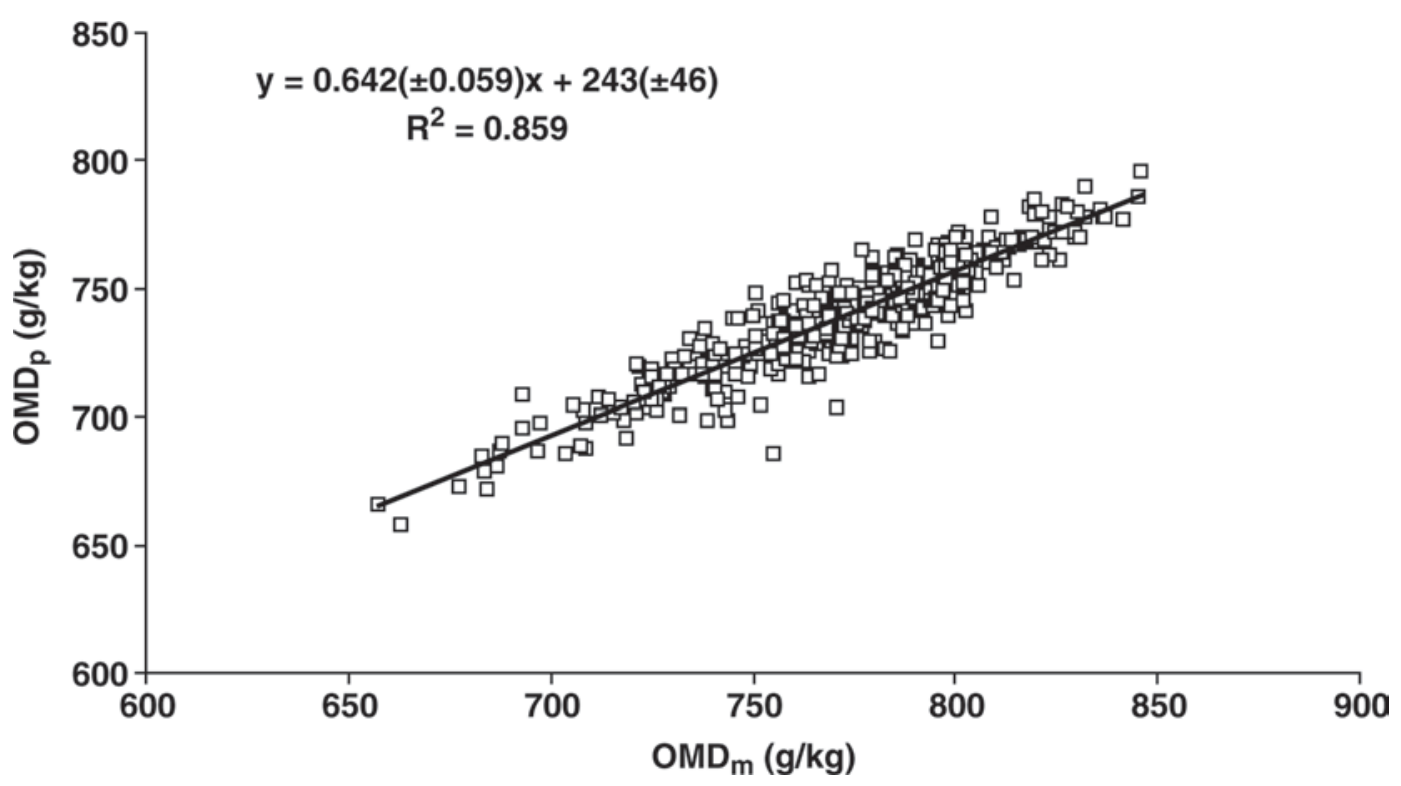

Figure 1. The relationship between the digestibility of $\mathrm{OM}$ estimated at a maintenance level of feeding $\left(\mathrm{OMD}_{\mathrm{m}}\right)$ and determined in vivo in lactating dairy cows $\left(\mathrm{OMD}_{\mathrm{p}}\right)$. The values are adjusted for a random study effect $(\mathrm{n}=497)$.

In the simulation study, the intercept and slope of the 20 in vitro correction equations averaged 54 and 0.87 , with corresponding standard error values of 18 and 0.024 . The error values of parameters as well as the mean prediction error $(10.2 \mathrm{~g} / \mathrm{kg})$ were similar to the original equation, suggesting that the error parameters of simulations were realistic. Intercepts and slopes of these 20 equations were strongly and inversely correlated $\left(\mathrm{R}^{2}=0.99\right)$. As expected, the prediction error of $\mathrm{OMD}_{\mathrm{p}}$ was greater when estimated using predicted $\mathrm{OMD}_{\mathrm{m}}$ as an input variable instead of using the determined in vitro OMS directly. However, quantitatively the difference was rather small (8.63 vs. 8.48), ranging from 0.00 to 0.85 . Proportionally, the increase in error was greater than $5 \%$ in 20 out of 400 simulations.

A multiple best-fit mixed model regression equation predicting $\mathrm{OMD}_{\mathrm{p}}$ in dairy cows from different feed and intake variables is shown in Table 2. The parameters are listed in the order of decreasing residual variance when included in the model. Inclusion of additional parameters after CP improved the model significantly, but the 2 last parameters showed only a tendency toward a better model. The parameter values for $\mathrm{OMD}_{\mathrm{m}}$ and DMI remained rather similar compared with the 2-variable model [7], indicating the biological stability and validity of the model. The correlation coefficients between the model parameters were small [the highest correlation between DMI and CFat (concentrate fat intake) was 0.43]. Within the practical range of input data, it is unlikely that the model prediction would deviate excessively from observed values. Interactions between the independent variables included in the $\mathrm{OMD}_{\mathrm{p}}$ model (Table 2) were not significant or resulted in nonsignificant main effects and markedly changed parameter values.

It is important to model factors influencing NDFD because most of the variation in $\mathrm{OMD}_{\mathrm{p}}$ is related to changes in the concentration and digestibility of the NDF fraction of the diet:

$$
\begin{aligned}
& \mathrm{OMD}_{\mathrm{p}}(\text { mixed model })=622( \pm 11)+0.390( \pm 0.016) \\
& \times \mathrm{NDFD}(\mathrm{g} / \mathrm{kg})-0.332( \pm 0.016) \times \mathrm{NDF} \\
& (\mathrm{g} / \mathrm{kg} \text { of } \mathrm{DM}) ; \text { adjusted RMSE }=6.9 \mathrm{~g} / \mathrm{kg} .
\end{aligned}
$$

The parameter values in the global regression model predicting $\mathrm{OMD}_{\mathrm{p}}$ from dietary NDF concentration and NDFD were quite similar to those estimated by the mixed model analysis taking into account the random study effect:

$$
\begin{gathered}
\mathrm{OMD}_{\mathrm{p}}(\text { global })=587( \pm 10)+0.434( \pm 0.012) \\
\times \mathrm{NDFD}(\mathrm{g} / \mathrm{kg})-0.314( \pm 0.019) \times \mathrm{NDF} \\
(\mathrm{g} / \mathrm{kg} \text { of DM }) ; \mathrm{RMSE}=16.2 \mathrm{~g} / \mathrm{kg} ; \mathrm{R}^{2}=0.79
\end{gathered}
$$

\section{Fiber Digestion}

A multiple regression equation including both intrinsic and extrinsic factors influencing NDFD in dairy cows is presented in Table 3 . The proportion of pdNDF 
Table 2. The best-fit equation for multiple regression of OM digestibility in lactating dairy $\operatorname{cows}^{1}(\mathrm{n}=497$; adjusted $\mathrm{RMSE}^{2}=7.1 \mathrm{~g} / \mathrm{kg}$; unadjusted RMSE $=21.6 \mathrm{~g} / \mathrm{kg}$ )

\begin{tabular}{llccc}
\hline Effect & Unit & Estimate & SE & $P$-value \\
\hline Intercept & & 18.4 & 54.0 & 0.73 \\
OMD $_{\mathrm{m}}{ }^{3}$ & $\mathrm{~g} / \mathrm{kg}$ of DM & 0.651 & 0.060 & $<0.001$ \\
DMI & $\mathrm{kg} / \mathrm{d}$ & -2.72 & 0.56 & $<0.001$ \\
Ln CP & 53.7 & 6.1 & $<0.001$ \\
Wcrop $^{5}$ & $\mathrm{~g} / \mathrm{kg}$ of DM & 22.2 & 20 & 0.37 \\
Wcrop $^{4} \times$ Wcrop & & -61.4 & 21 & 0.003 \\
Cfat $^{6}$ & $\mathrm{~g} / \mathrm{kg}$ of DM & -17.7 & 6 & 0.002 \\
\hline
\end{tabular}

${ }^{1}$ All values are adjusted for the random study effect.

${ }^{2} \mathrm{RMSE}=$ residual mean square error.

${ }^{3}$ Organic matter digestibility determined at a maintenance level of feeding in sheep or with a corresponding in vitro method.

${ }^{4}$ Natural logarithm of CP concentration.

${ }^{5}$ Proportion of whole-crop cereal silage in forage $(\mathrm{kg} / \mathrm{kg})$.

${ }^{6}$ Concentrate fat intake.

of total NDF, which expresses the potential extent of digestion (i.e., intrinsic factor of plant characteristics determining the potential extent of digestion), had the strongest effect (smallest Akaike's information criterion and RMSE) on NDFD in cows. Digestibility of NDF decreased as intake increased. The ratio of NFC to NDF and the proportion of whole-crop silage in forage DM depressed NDFD quadratically, whereas concentrate fat depressed it linearly $(P<0.05)$. Increased dietary $\mathrm{CP}$ concentration was associated with improved NDFD.

\section{Digestion of NDS and Output of Metabolic Fecal OM}

An equation for predicting true NDS digestibility and metabolic fecal OM (MFOM) output based on the Lucas test was developed by using the whole data set:

$$
\begin{aligned}
& \text { Digestible NDS }(\mathrm{g} / \mathrm{kg} \text { of DM })=-84( \pm 1.0) \\
& +0.975( \pm 0.021) \times \mathrm{NDS}(\mathrm{g} / \mathrm{kg} \text { of } \mathrm{DM}) \\
& \text { adjusted RMSE }=5.8 \mathrm{~g} / \mathrm{kg} .
\end{aligned}
$$

Compared with the Lucas test, the fit of models using the same parameters as $\mathrm{OMD}_{\mathrm{p}}$ and the NDFD models for predicting MFOM did not markedly improve the fit (models not shown), and most of the parameters were statistically nonsignificant, indicating that diet composition and DMI do not influence fecal output of NDS in cows fed mainly grass silage-based diets. However, when the grain type was classified as corn compared with small grains (barley, oats, and wheat), feeding corn-based concentrates increased MFOM by $19 \mathrm{~g} / \mathrm{kg}$ of DMI $(P<0.001)$, indicating increased fecal starch output.

\section{TDN Discounts}

Both the NRC and CNPCS models overestimated the total discount in $\mathrm{TDN}_{\mathrm{p}}$ intake (Figure 2). The dif- ference between observed TDN intake in cows $\left(\mathrm{TDN}_{\mathrm{p}}\right)$ and $\mathrm{TDN}_{\mathrm{m}}$ was $0.75 \mathrm{~kg} / \mathrm{d}$. Evaluation of the CNCPS and NRC models with the observed data resulted in both significant $(P<0.001)$ mean biases of -0.55 and $-0.77 \mathrm{~kg} / \mathrm{d}$ and linear biases of -0.41 and -0.55 , respectively (Figure 3).

An equation for predicting the TDN discount (difference between TDN intake estimated at maintenance intake and that observed in dairy cows) was developed by using the significant independent variables of the $\mathrm{OMD}_{\mathrm{p}}$ model (Table 4). The final model was reduced to include 4 parameters because the effect of concentrate water-soluble carbohydrates was not significant and the quadratic effect of $\mathrm{CP}$ and concentrate fat intake did not decrease residual error despite being significant.

\section{DISCUSSION}

Studies investigating the feeding level effect on diet digestibility are difficult to conduct in dairy cows. A wide range in intake cannot be obtained without confounding effects (stage of lactation, changes in environment, feed quality, etc.). The digestibility depressions within a single study are usually not large enough for quantification of the differences, especially deviations from linearity (Van Soest, 1994), because the depressions in digestibility with intake and especially interactions between diet composition and intake level are difficult to detect. Another alternative is to apply regression analysis on meta-data and use digestibility estimated at a maintenance feeding level as a dependent variable in the model. Mixed model analysis (St-Pierre, 2001) allows the variation between studies to be excluded and estimates the relationships between the variables within a study. Adjusting the data for a random study effect reduced RMSE values markedly compared with unadjusted values. The small adjusted RMSE indicates that the differences between the diets within a 
Table 3. The best-fit equation for multiple regression of NDF digestibility in lactating dairy $\operatorname{cows}^{1}(\mathrm{n}=394$; adjusted $\mathrm{RMSE}^{2}=12.4 \mathrm{~g} / \mathrm{kg}$; unadjusted RMSE $=40.1 \mathrm{~g} / \mathrm{kg}$ )

\begin{tabular}{llccc}
\hline Item & Unit & Estimate & SE & $P$-value \\
\hline Intercept & & -285 & 130 & 0.03 \\
pdNDF $^{3} / \mathrm{NDF}$ & g/kg of NDF & 0.647 & 0.131 & $<0.001$ \\
DMI & $\mathrm{kg} / \mathrm{d}$ & -4.85 & 1.43 & $<0.001$ \\
Wcrop $^{4}$ & & -28 & 39.2 & $<0.48$ \\
Wcrop $\times$ Wcrop & & -70 & 39.3 & 0.08 \\
$(\mathrm{NFC} / \mathrm{NDF}) \times(\mathrm{NFC} / \mathrm{NDF})$ & $\mathrm{g} / \mathrm{kg}$ of DM & 101 & 6.8 & $<0.001$ \\
Ln CP $^{5}$ & $\mathrm{~kg} / \mathrm{d}$ & -33 & 14.3 & $<0.001$ \\
Cfat $^{6}$ & & & 15.6 & 0.04 \\
\hline
\end{tabular}

${ }^{1}$ All values are adjusted for the random study effect.

${ }^{2} \mathrm{RMSE}=$ residual mean square error.

${ }^{3} \mathrm{pdNDF}=$ potentially digestible NDF.

${ }^{4}$ Proportion of whole-crop cereal silage in forage $(\mathrm{kg} / \mathrm{kg})$.

${ }^{5}$ Natural logarithm of $\mathrm{CP}$ concentration.

${ }^{6}$ Concentrate fat intake.

trial could be predicted accurately. The unexplained variation that makes up the random study effect can be attributed to various factors. Variation between laboratories in the determination of both in vitro and in vivo $\mathrm{OMD}_{\mathrm{m}}$ is undoubtedly an important component of the random study effect. Previous research comparing digestibility of the same hay indicated considerable variation in digestion coefficients between laboratories (see Cochran and Galyean, 1993). Part of the random study effect could be attributed to the random animal effects within the laboratory. In vivo digestibility in sheep at maintenance and dairy cows at a production level are determined only with a limited number of animals. Animal variation in digestibility is much greater than variation related to the collection period (Cochran and Galyean, 1993), which increases random variation for both $\mathrm{OMD}_{\mathrm{m}}$ and $\mathrm{OMD}_{\mathrm{p}}$. True variation within concentrate ingredients was ignored by using tabulated digestibility coefficients. Interlaboratory differences as well as intralaboratory within-run variation of in vitro $\mathrm{OMD}_{\mathrm{m}}$ are also included in the variation between studies. Even between-laboratory variation in the analysis of CP or concentrate fat (with or without hydrochloric acid hydrolysis) could have contributed to the random study effect in the present study. For example, the coefficient of variation of CP concentration of 5 feeds was on average $4.4 \%$ in 23 European laboratories (Madsen and Hvelplund, 1994).

\section{OMD}

In many current feed energy systems for ruminants, the energy values are based on digestibility coefficients estimated with sheep at a maintenance level of feeding (INRA, 1989; Agricultural and Food Research Council, 1990; Yan et al. 2002). Laboratory methods used to estimate forage digestibility $\left(\mathrm{OMD}_{\mathrm{m}}\right)$ or energy concentration are usually calibrated against digestibility measured with sheep at a maintenance level of feeding (Huhtanen et al., 2006). In the present data set, in vitro digestibility was determined typically either by the method of Tilley and Terry (1963) using a 48-h incubation in rumen fluid or by the pepsin-cellulase method described by Nousiainen et al. (2003). Both these methods have resulted in small prediction errors of $\mathrm{OMD}_{\mathrm{m}}$ (Tilley and Terry, 1963; Huhtanen et al., 2006).

Although the proportion of hindgut digestion is greater in sheep than cattle (Tamminga, 1993), the overall digestive capacity of sheep and cattle is similar. Mertens and Ely (1982) reported a slope significantly different from 1, but within the range of practical dairy cow diets, the influence of slope bias was small. More recently, Yan et al. (2002) conducted a comprehensive analysis of 72 comparisons published since 1951. The linear relationship of OMD measured at or near maintenance level was very good for mixed diets and high-quality forages; only for the poor-quality forages $\left(\mathrm{OMD}_{\mathrm{m}}<500 \mathrm{~g} / \mathrm{kg}\right)$ did the models predict a higher value for cattle. The analysis of Yan et al. (2002) suggests that digestibility coefficients estimated with sheep at a maintenance level of feeding form a valid basis for energy evaluation systems.

The linear slope between $\mathrm{OMD}_{\mathrm{m}}$ and $\mathrm{OMD}_{\mathrm{p}}$ in the present study (0.64; see Figure 1) compares well with the value of 0.68 reported by Yan et al. (2002) for the corresponding relationship in digestible energy. In their study, both sheep and cow values were determined in vivo, whereas in our study, "sheep" data were estimated from determined (in vivo sheep or in vitro) forage digestibility and were estimated for the concentrate part of the diet from chemical composition and tabulated 

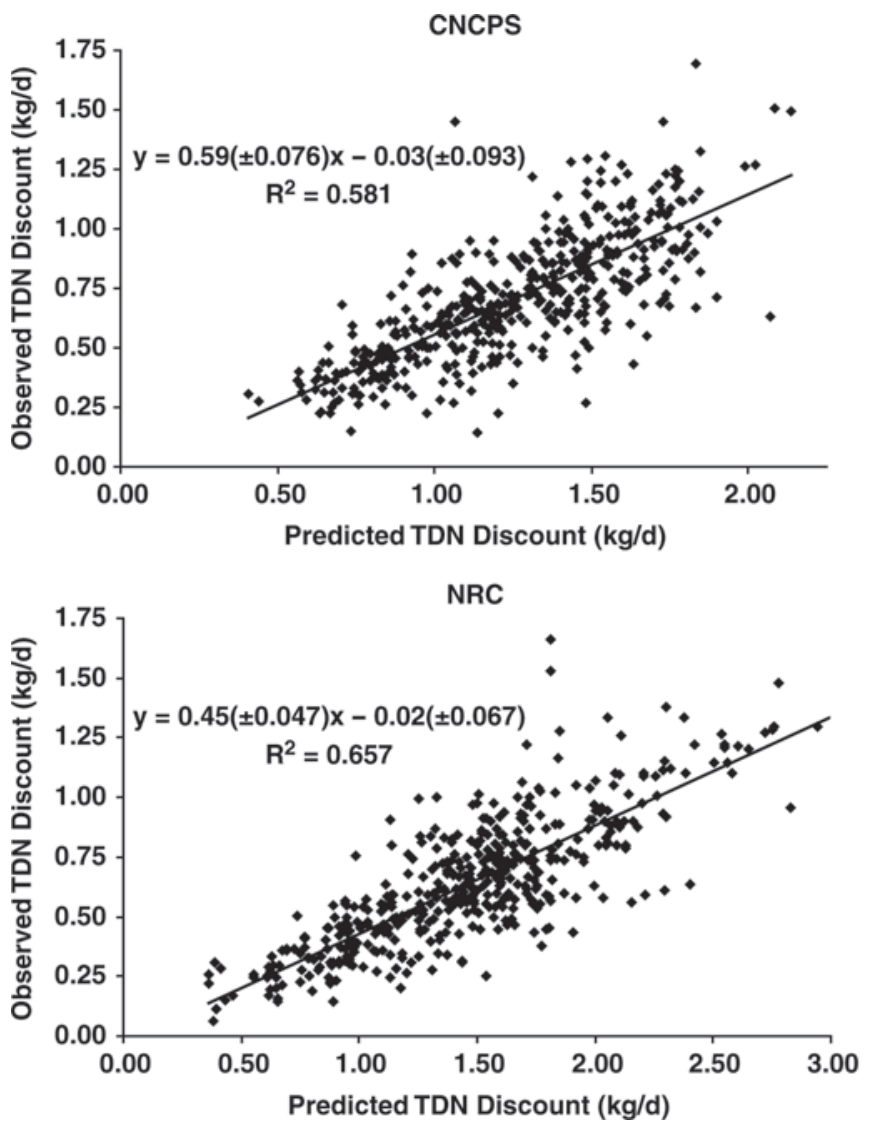

Figure 2. Relationships between predicted [Cornell Net Carbohydrate and Protein System (CNCPS) and NRC] and observed total digestible nutrient $(\mathrm{TDN})$ discounts $(\mathrm{n}=470)$. The values are adjusted for random study effects. Observed TDN discount is the difference in TDN intake calculated by using digestibility estimated at a maintenance level of feeding and TDN intake measured in lactating dairy cows.

digestibility coefficients. The present analysis strongly indicates that in vitro methods provide useful data for predicting digestibility at production levels in dairy cows, provided the methods are calibrated against digestibility measured in sheep at maintenance. Including the random study effect in the model decreased RMSE

Table 4. The multiple regression equation for total digestible nutrient (TDN) discounts $\left(\mathrm{n}=497\right.$, adjusted $\mathrm{RMSE}^{1}=0.13 \mathrm{~kg}$, unadjusted $\mathrm{RMSE}=0.39 \mathrm{~kg})^{2}$

\begin{tabular}{llclc}
\hline Effect & Unit & Estimate & $\mathrm{SE}$ & $P$-value \\
\hline Intercept & & -4.73 & 0.839 & $<0.001$ \\
$\mathrm{OMD}_{\mathrm{m}}{ }^{3}$ & $\mathrm{~g} / \mathrm{kg}$ of $\mathrm{DM}$ & 0.085 & 0.0096 & $<0.001$ \\
$\mathrm{DMI}$ & $\mathrm{kg} / \mathrm{d}$ & 0.0059 & 0.0011 & $<0.001$ \\
$\mathrm{CP}$ & $\mathrm{g} / \mathrm{kg}$ of DM & -0.0051 & 0.0007 & $<0.001$ \\
Wcrop $\times \mathrm{Wcrop}^{4}$ & & 0.742 & 0.144 & $<0.001$ \\
\hline
\end{tabular}

${ }^{1} \mathrm{RMSE}=$ residual mean square error.

${ }^{2}$ All values are adjusted for the random study effect.

${ }^{3} \mathrm{OM}$ digestibility determined at a maintenance level of feeding in sheep or with a corresponding in vitro method.

${ }^{4}$ Proportion of whole-crop cereal silage in forage $(\mathrm{kg} / \mathrm{kg})$.
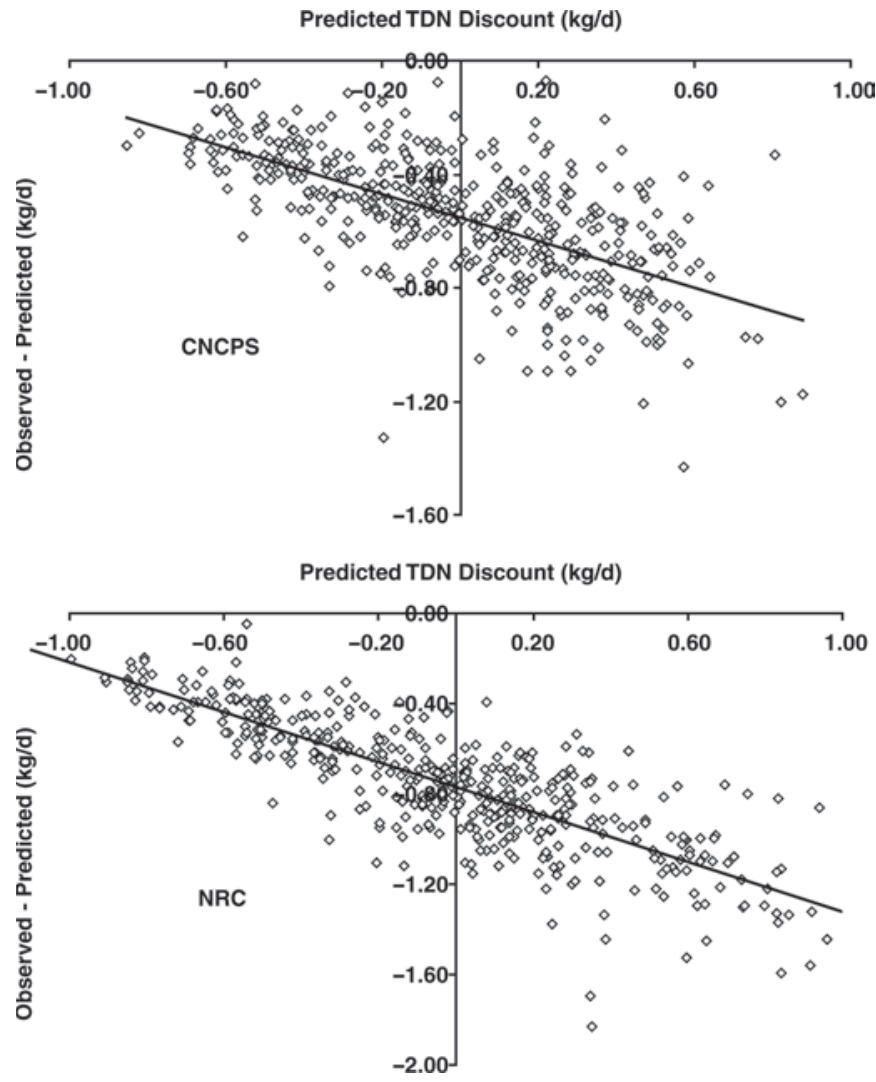

Figure 3. Plot of residuals (observed - predicted) versus predicted total digestible nutrient (TDN) discounts estimated according to the Cornell Net Carbohydrate and Protein System (CNCPS) and NRC. The regression lines in the graph represent the equation $\mathrm{y}=-0.55$ $( \pm 0.008)-0.41( \pm 0.023) \mathrm{x}$ and $\mathrm{y}=-0.77( \pm 0.007)-0.55( \pm 0.015) \mathrm{x}$ for the CNCPS and NRC models, respectively. Predicted values were centered by subtracting the mean of all predicted values from each predicted value.

more for $\mathrm{OMD}_{\mathrm{m}}$ estimated in vitro than with the in vivo data, which may be related to greater betweenlaboratory variation in vitro compared with in vivo digestibility. However, when the data were adjusted for the random study effect, the RMSE was not greater for the in vitro data, indicating that differences in OMD of dairy cow diets can be predicted accurately from the in vitro data.

It is important to note that using predicted values $\left(\mathrm{OMD}_{\mathrm{m}}\right.$ derived from in vitro data) to predict a new output $\left(\mathrm{OMD}_{\mathrm{p}}\right)$ results in compounded variance that amplifies the error. When the in vitro calibration is based on a large data set with a wide range of digestibility values, as in our OMS calibration $(\mathrm{n}=86$; range in $\mathrm{OMD}_{\mathrm{m}} 581$ to $840 \mathrm{~g} / \mathrm{kg}$ ), the covariance between the parameter estimates is not likely to markedly increase the error of $\mathrm{OMD}_{\mathrm{p}}$ prediction. However, if the in vitro calibrations are based on a small number of samples with a limited range in $\mathrm{OMD}_{\mathrm{m}}$, it is possible that the error of $\mathrm{OMD}_{\mathrm{p}}$ would be amplified markedly when es- 
timated from predicted $\mathrm{OMD}_{\mathrm{m}}$. It should also be noted that our data set includes in vitro data estimated by using the original procedure of Tilley and Terry (1963), which does not always include the use of correction equations.

In the present meta-analysis, total diet $\mathrm{OMD}_{\mathrm{p}}$ in dairy cows was on average $38 \mathrm{~g} / \mathrm{kg}$ lower than $\mathrm{OMD}_{\mathrm{m}}$ (736 vs. $774 \mathrm{~g} / \mathrm{kg}$; Table 1$)$. The relative decrease in $\mathrm{OMD}_{\mathrm{p}}$ per multiple of maintenance feeding was $2.0 \%$ $(15 \mathrm{~g} / \mathrm{kg})$. The proportional decrease was close to the value of $2.5 \%$ reported by Yan et al. (2002) for grass silage-based diets, but was markedly smaller than the value of $4 \%$ reported by Tyrrel and Moe (1975) and adopted by NRC (2001). The greater depression in digestibility in the NRC (2001) system may be related to the decrease in the digestibility of corn starch and other NDS with increased feeding level (Colucci et al., 1982, 1989). In agreement with this view, Gabel et al. (2003) reported a depression of 3.2, 5.0, and $2.5 \%$ in $\mathrm{OM}$, NDF, and starch digestibility, respectively, per incremental increase in feeding level in dairy cows fed a diet based mainly on corn silage.

Calculated apparent MFOM increased by 1.8 to 2.1 $\mathrm{g} / \mathrm{kg}$ per kilogram of increase in DMI in the studies of Colucci et al. (1989) and Gabel et al. (2003) with diets containing cracked corn or corn silage, with starch being the main component in this increase. In the present data, the true digestibility of NDS was 0.99 (Nousiainen et al., 2009) and MFOM output was not related to dietary starch concentration. Consistent with this result, Volden (1999) did not observe any intake-level response in ruminal starch digestibility in dairy cows fed barley- and oats-based concentrates. Similarly, starch digestibility remained above $99 \%$ when dietary starch concentration was gradually increased by substituting whole-crop barley silage for grass silage (Ahvenjärvi et al., 2006).

The linear depression in digestibility (equation [7]) is in line with feed evaluation systems adopting linear discounts in digestibility or energy concentration with increased intake (e.g., van Es, 1975; Agricultural and Food Research Council, 1993; NRC 2001). However, the assumption of linearity has not been adequately tested. Van Soest et al. (1992) suggested that the decline in digestibility is proportional to the inverse of the square of intake. In the models of Vandehaar (1998), depression was proportional to the 0.8 power of feeding level above maintenance. Our data do not support the curvilinear declines in digestibility with increased intake. Recently, Gabel et al. (2003) fed sheep $1.4 \times$ the maintenance level and cows 2.7 to $2.8 \times$ and 4.6 to $5.0 \times$ the maintenance levels of diets based on corn silage and found no deviation from linearity.
The depression in digestibility per unit of increase in DMI increased as $\mathrm{OMD}_{\mathrm{m}}$ increased, which is consistent with the NRC (2001) discount equation and the equations developed by Yan et al. (2002). Similar interactions were observed by Tyrrel and Moe (1975) and Colucci et al. $(1982,1989)$ in cows fed diets based on corn silage, alfalfa hay or haylage, and cracked corn. The decrease in digestibility with increased intake is essentially due to increased cell wall passage rates and decreased ruminal retention time.

In the studies by Colucci et al. (1989, 1990), there was a close relationship $\left(\mathrm{R}^{2}=0.86\right)$ between the decrease in ruminal retention time and depression in digestibility in sheep and cows fed different diets. At the maintenance level of feeding, the rumen residence time is much longer for low-concentrate compared with high-concentrate diets (Colucci et al., 1982, 1990), which allows compensation for the reduced NDF digestion rates with high-concentrate diets at low levels of feeding. When the feeding level increases, the rumen residence time decreases more with high-concentrate than with low-concentrate diets (Colucci et al., 1982, 1990); consequently, the effects of reduced digestion rate on NDFD cannot be compensated for as they can at a maintenance level of feeding.

The negative effect of the substitution of wholecrop silages for grass silages could partly be related to reduced fiber digestion of grain fiber at high intakes (Table 3). The gradual replacement of grass silage with whole-crop barley silage decreased the digestibility of pdNDF in dairy cows (Ahvenjärvi et al., 2006). The authors suggested this effect was related to the selective mechanism of digesta retention in the rumen and that whole-crop barley silage particles were released from the nonescapable pool to the escapable particle pool at a higher rate compared with grass silage.

A recent study by Lund et al. (2006) also indicated that retention of feed particles was less selective for corn and whole-crop barley silages compared with early-harvested grass silage. The better fit of the quadratic model suggests that selectivity of particle retention is gradually lost as the proportion of whole-crop silages in forage increases. Indirect comparison of the feeding level effects indicates that effects of feeding level on digestibility are greater for corn silage-based diets (Gabel et al., 2003) than for grass silage-based diets (Volden, 1999).

Although $\mathrm{OMD}_{\mathrm{p}}$ did not equal $\mathrm{OMD}_{\mathrm{m}}$, the developed models suggest that digestibility and energy values of dairy cow diets can be predicted accurately and precisely by $\mathrm{OMD}_{\mathrm{m}}$ estimated in vivo in sheep or in vitro by taking into account the effects of feeding level and associative effects of dietary components. 


\section{NDF and NDS Digestibility}

The decrease in NDFD with the best-fit model (Table 3) was $4.85 \mathrm{~g} / \mathrm{kg}$ of DMI, which corresponds to a depression of $2.64 \mathrm{~g} / \mathrm{kg}$ in $\mathrm{OMD}_{\mathrm{p}}$, indicating that most of the depression in $\mathrm{OMD}_{\mathrm{p}}$ can be attributed to a decrease in NDFD as intake is increased. This association may partly be related to the correlation of errors in OMD and NDFD. However, the lack of important dietary or animal effects on MFOM, the small standard errors of the parameters of the Lucas equation and the small RMSE of $\mathrm{OMD}_{\mathrm{p}}$ do not support a major role of error correlation in explaining the contribution of NDF on digestibility depression. The Lucas equation developed from the present dairy cow data set had intercept and slope values similar to those derived by Weisbjerg et al. (2004) for 499 diets with a wide range in chemical composition and by Huhtanen et al. (2006) for 86 silage-only diets. In both studies, the diets were fed at a maintenance level to sheep.

As expected, NDFD was positively associated with potential NDFD (pdNDF/NDF) determined by a 12-d ruminal in situ incubation, but the slope was markedly below 1 (Table 3 ). In the present study, the relationship between intake and NDFD was linear. Including either a quadratic effect of DMI or using a power $>1.0$ suggested that if there were any curvilinearity, the depression in NDFD would increase as feed intake increased. Kinetically decreasing depression in digestibility with increased intake is questionable because the rumen NDF pool size should increase quadratically unless the rate of NDF digestion also increases with enhanced DMI, which is unlikely.

The effect of whole-crop cereal silage inclusion on NDFD (Table 3) was consistent with that observed in $\mathrm{OMD}_{\mathrm{p}}$ (Table 2), suggesting that the depression in $\mathrm{NDFD}_{\mathrm{m}}$ accounted for the decrease in $\mathrm{OMD}_{\mathrm{p}}$. The negative quadratic effect of increasing $\mathrm{NFC} / \mathrm{NDF}$ on $\mathrm{NDFD}_{\mathrm{m}}$ in the diet can be related to 2 mechanisms. First, increasing NFC/NDF inhibits ruminal cellulolytic bacteria. Usually this ratio is closely related to the proportion of concentrate in the diet, and replacing NFC/ NDF with the proportion of concentrate in the model only slightly increased the prediction error.

Second, NFC/NDF was positively correlated with the proportion of concentrate in the diet $(\mathrm{r}=0.62)$; consequently, the proportion of concentrate fiber in total NDF increased with NFC/NDF. Finer (concentrate) particles have a faster passage rate than forage particles (Colucci et al., 1990; Wylie et al., 2000); therefore, concentrate fiber can contribute more to digestibility depression with increased intake, as discussed by Van Soest (1994). Large depressions in digestibility were observed when the intake of high-concentrate diets based on fibrous concentrates was increased (Woods et al., 1999). Protein supplementation had a stimulatory effect on NDFD similar to that observed specifically in protein supplementation studies (Nousiainen et al., 2009).

\section{TDN Discounts}

Both the NRC (2001) and CNCPS (Fox et al., 2004) models markedly overestimated the TDN discount in dairy cows fed grass silage-based diets (Figure 2). The mean bias had the major contribution to MSPE, but in both systems, the slope between observed and predicted discounts was significantly less than 1 . In the CNCPS system, the prediction error (observed - predicted) was significantly $(P<0.001)$ and positively related to the amount or proportion of concentrate in the diet and to $\mathrm{OMD}_{\mathrm{m}}$. This indicates that CNCPS overestimated the reduction in TDN concentration with increased DMI more for high-forage diets than for high-concentrate diets.

The CNCPS separately estimates $\mathrm{TDN}_{\mathrm{p}}$ concentrations with increased intake for forage and concentrate portions of the diet. In the present data, estimated decreases in $\mathrm{TDN}_{\mathrm{p}}$ were 19.6 and $32.4 \mathrm{~g} / \mathrm{kg}$ of $\mathrm{DM}$ for average concentrates and forages $\left(\mathrm{TDN}_{\mathrm{m}}\right.$ of 799 and $709 \mathrm{~g} / \mathrm{kg}$ of DM). The greater discount for forages in the CNCPS disagrees with NRC (2001) and our 2-factor $\left(\mathrm{OMD}_{\mathrm{m}}+\mathrm{TDMI}\right) \mathrm{OMD}_{\mathrm{p}}$ equation, which predicts a greater depression in digestibility for high-TDN $\mathrm{m}_{\mathrm{m}}$ diets.

As discussed earlier, the significant mean and slope bias in TDN discounts can be related to greater and variable depressions in starch digestibility with diets containing corn silage, grain, or both as feed intake is increased. In the present data, the mean starch intake was $2.65 \mathrm{~kg} / \mathrm{d}$. To account completely for the difference between the observed and NRC (2001)-predicted difference in the TDN discount $(0.74 \mathrm{~kg})$, the starch digestibility should have been $720 \mathrm{~g} / \mathrm{kg}$. This is markedly less than the apparent total digestibility of starch in cows fed corn grain processed by different methods (Firkins et al., 2001). The lowest value reported in their metaanalysis was $850 \mathrm{~g} / \mathrm{kg}$ for dried cracked corn, whereas the values for other types of corn grain ranged from 888 (steam-rolled corn) to $988 \mathrm{~g} / \mathrm{kg}$ (high-moisture, ground corn). However, it should be noted that increases in fecal starch output are also associated with changes in fecal nitrogen output because a portion of the starch is fermented in the hindgut (Reynolds et al., 2001). Recalculation from Colucci et al. (1990) and Gabel et al. (2003) indicated a very close relationship between apparent output of MFOM and starch. The following relationship between MFOM and starch concentration 
was calculated from their data: fecal MFOM $(\mathrm{g} / \mathrm{kg}$ of $\mathrm{DMI})=95+1.4 \times$ fecal starch $\left(\mathrm{g} / \mathrm{kg}\right.$ of $\mathrm{DMI} ; \mathrm{R}^{2}=$ 0.91 ); that is, a 1-unit increase in fecal starch output was associated with a 1.4-unit increase in fecal MFOM.

\section{CONCLUSIONS}

The digestibility of dairy cow diets can be predicted accurately and precisely from digestibility determined at a maintenance level of feeding in sheep. Moreover, in vitro digestibility data for the forage component of the diet proved to be at least as reliable in predicting OMD in cows as the in vivo data derived from sheep fed forage at a maintenance level of feeding. The regression equations developed indicated that the level of feed intake and digestibility determined at maintenance are the most important factors influencing diet digestibility in cows. Variation in the fiber fraction (i.e., amount and digestibility) of the diets accounted for most of the variation in the digestibility of grass silage-based diets. Diets with a high digestibility at maintenance exhibited greater depressions in digestibility with increased intake.

\section{REFERENCES}

Agricultural and Food Research Council. 1993. Energy and protein requirements of ruminants. An advisory manual prepared by the AFRC Technical Committee on Responses to Nutrients. CAB International, Wallingford, UK.

Agricultural and Food Research Council. 1990. Technical Committee on Response to Nutrients. Report number 5. Nutritive requirements of ruminant animals: Energy. Nutr. Abst. Rev. Ser. B 60:729-804.

Ahvenjärvi, S., E. Joki-Tokola, A. Vanhatalo, S. Jaakkola, and P. Huhtanen. 2006. Whole-crop barley silage for dairy cow diets. J. Dairy Sci. 89:1678-1687.

Bibby, J., and H. Toutenburg. 1977. Prediction and Improved Estimation of Linear Models. John Wiley and Sons, London, UK.

Cochran, R. C., and M. L. Galyean. 1993. Measurement of in vivo forage digestion by ruminants. Pages 613-639 in Forage Quality, Evaluation, and Utilization. G. C. Fahey, M. Collins, D. R. Mertens, and L. E. Lowell, ed. Am. Soc. Agron., Madison, WI.

Colucci, P. E., L. E. Chase, and P. J. Van Soest. 1982. Feed intake, apparent diet digestibility, and rate of particulate passage in dairy cattle. J. Dairy Sci. 65:1445-1456.

Colucci, P. E., G. K. MacLeod, W. L. Grovum, L. W. Cahill, and I. McMillan. 1989. Comparative digestion in sheep and cattle fed different forage to concentrate ratios at high and low intakes. J. Dairy Sci. 72:1774-1785.

Colucci, P. E., G. K. MacLeod, W. L. Grovum, I. McMillan, and D. J. Barney. 1990. Digesta kinetics in sheep and cattle fed diets with different forage to concentrate ratios at high and low intakes. J. Dairy Sci. 73:2143-2156.

Firkins, J. L., M. L. Eastridge, N. R. St-Pierre, and S. M. Noftsger. 2001. Effects of grain variability and processing on starch utilization by lactating dairy cattle. J. Anim. Sci. 79(E Suppl.):E218-E238.

Fox, D. G., L. O. Tedeschi, T. P. Tylutki, J. B. Russel, M. E. Van Amburg, L. E. Chase, A. N. Pell, and T. R. Overton. 2004. The Cornell Net Carbohydrate and Protein model for evaluation herd nutrition and nutrient excretion. Anim. Feed Sci. Technol. 112:29-78.
Fox, D. G., P. Tylutki, L. O. Tedeschi, M. E. Van Amburg, L. E. Chase, A. N. Pell, T. R. Overton, and J. B. Russel. 2003. The Net Carbohydrate and Protein System for evaluating herd nutrition and nutrient excretion. Version 5.0. Animal Science Department Mimeo 213. Cornell University, Ithaca, NY.

Gabel, M., B. Pieper, K. Friedel, M. Radke, A. Hagemann, J. Voigt, and S. Kuhla. 2003. Influence of nutrition level on digestibility in high yielding cows and effects on energy evaluation systems. J. Dairy Sci. 86:3992-3998.

Huhtanen, P., J. Nousiainen, and M. Rinne. 2006. Recent developments in forage evaluation with special reference to practical applications. Agric. Food Sci. 15:293-323.

INRA. 1989. Ruminant Nutrition: Recommended Allowances and Feed Tables. R. Jarrige, ed. INRA, Paris, France.

Littell, R. C., G. A. Milliken, W. W. Stroup, and R. D. Wolfinger. 1996. SAS System for Mixed Models. SAS Inst. Inc., Cary, NC.

Lund, P., M. R. Weisbjerg, and T. Hvelplund. 2006. Digestible NDF is selectively retained in the rumen of dairy cows compared to indigestible NDF. Anim. Feed Sci. Technol. 134:1-17.

Madsen, J., and T. Hvelplund. 1994. Prediction of in situ protein degradability in the rumen. Results of a European ringtest. Livest. Prod. Sci. 39:201-212.

Mertens, D. R., and L. O. Ely. 1982. Relationship of rate and extent of digestion to forage utilization-A dynamic model evaluation. J. Anim. Sci. 54:895-905.

Nousiainen, J. 2004. Development of tools for the nutritional management of dairy cows on silage-based diets. $\mathrm{PhD}$ thesis, University of Helsinki. Retrieved July 24, 2009, from http:// ethesis.helsinki.fi/julkaisut/maa/kotie/vk/nousiainen

Nousiainen, J., M. Rinne, M. Hellämäki, and P. Huhtanen. 2003. Prediction of the digestibility of the primary growth of grass silages harvested at different stages of maturity from chemical composition and pepsin cellulase solubility. Anim. Feed Sci. Technol. 103:97-111.

Nousiainen, J., M. Rinne, and P. Huhtanen. 2009. A meta-analysis of feed digestion in dairy cows. 1 . The effects of forage and concentrate factors on total diet digestibility. J. Dairy Sci. 92:5019-5030.

NRC. 2001. Nutrient Requirements of Dairy Cattle. 7th rev. ed. Natl. Acad. Press, Washington, DC.

Reynolds, C. K., S. B. Cammell, D. J. Humphries, D. E. Beever, J. D. Sutton, and J. R. Newbold. 2001. Effects of postrumen starch infusion on milk production and energy metabolism in dairy cows. J. Dairy Sci. 84:2250-2259.

St-Pierre, N. R. 2001. Integrating quantitative findings from multiple studies using mixed model methodology. J. Dairy Sci. 84:741755.

St-Pierre, N. R. 2003. Reassessment of biases in predicted nitrogen flows to the duodenum by NRC 2001. J. Dairy Sci. 86:344-350.

Tamminga, S. 1993. Influence of feeding management on ruminant fiber digestibility. Pages 571-602 in Forage Cell Wall Structure and Digestibility. H. G. Jung, D. R. Buxton, R. D. Hatfield, and J. Ralph, ed. Am. Soc. Agron., Madison, WI.

Tilley, J. M. A., and R. A. Terry. 1963. A two stage technique for the in vitro digestion of forage crops. J. Br. Grassl. Soc. 18:104-111.

Tyrrel, H. F., and P. W. Moe. 1975. Effect of intake on digestive efficiency. J. Dairy Sci. 58:1151-1163.

van Es, A. J. H. 1975. Feed evaluation for dairy cows. Livest. Prod. Sci. 2:95-107.

Van Keulen, J., and B. A. Young. 1977. Evaluation of acid-insoluble ash as a natural marker in ruminant digestibility studies. J. Anim. Sci. 44:282-287.

Van Soest, P. J. 1994. Nutritional Ecology of the Ruminant. 2nd ed. Cornell University Press, Ithaca, NY.

Van Soest, P. J., M. B. Rymph, and D. G. Fox. 1992. Discounts for net energy and protein - fifth edition. Pages 40-68 in Proc. Cornell Nutr. Conf., Ithaca, NY.

Vandehaar, M. J. 1998. Efficiency of nutrient use and relationship to profitability of dairy farms. J. Dairy Sci. 81:272-282.

Volden, H. 1999. Effects of level of feeding and ruminally undegraded protein on ruminal bacterial protein synthesis, escape of dietary 
protein, intestinal amino acid profile, and performance of dairy cows. J. Anim. Sci. 77:1905-1918.

Weisbjerg, M. R., T. Hvelpund, and K. Søegaard. 2004. Prediction of digestibility of neutral detergent solubles using the Lucas principle. J. Anim. Feed Sci. 13(Suppl. 1):239-242.

Woods, V. B., A. P. Moloney, F. J. Mulligan, M. J. Kenny, and F. P. O'Mara. 1999. The effect of animal species (cattle or sheep) and level of intake on in vivo digestibility of concentrate ingredients. Anim. Feed Sci. Technol. 80:135-150.
Wylie, M. J., W. C. Ellis, J. H. Matis, E. M. Bailey, W. D. James, and D. E. Beever. 2000. The flow of forage particles and solutes through segments of the digestive tract of cattle. Br. J. Nutr. 83:295-306

Yan, T., R. E. Agnew, and F. J. Gordon. 2002. The combined effects of animal species (sheep versus cattle) and level of feeding on digestible and metabolizable energy concentrations in grass silagebased diets of cattle. Anim. Sci. 75:141-151. 